\title{
Powtórzenie niemożliwe. O estetycznym doświadczeniu przeszłości w Pannach z Wilka Jarosława Iwaszkiewicza
}

\begin{abstract}
Górska Irena, Powtórzenie niemożliwe. O estetycznym doświadczeniu przeszłości w Pannach z Wilka Jarosława Iwaszkiewicza [Repetition Impossible. On the Aesthetic Experience of the Past in Jarosław Iwaszkiewicz's The Wilko Girls]. „Przestrzenie Teorii” 33. Poznań 2020, Adam Mickiewicz University Press, pp. 229-244. ISSN 1644-6763. DOI 10.14746/pt.2020.33.11.

The author attempts to describe the aesthetic experiences of the past lived by the protagonist of Jarosław Iwaszkiewicz's The Wilko Girls, and answer the question about the possibility of repetition. Elaborating on the arguments proposed by Friedrich Nietzsche in The Gay Science and by Søren Kierkegaard in Repetition, the author proves that even with a favourable attitude to one's own past, an attempt to repeat past experiences is impossible. Nothing can be experienced again. The past is closed. The possibility of only partial access to it is created by human sensuality referring to the notion of aisthesis, which is the source of aesthetic experience. The senses stimulated by various sounds, smells, tastes, images, and the accompanying memories and emotions, constitute a vast spectrum of aesthetic experiences, making the experience of the past an existential experience of time.
\end{abstract}

KEYWORDS: repetition, aesthetic experience, sensuality, past, time

Jako domena doświadczenia normatywnego, estetyczność na każdym kroku zaznacza swoja obecność $w$ świecie człowieka ${ }^{1}$.

Czy możliwe jest powtórzenie tego, co już było, co należy do przeszłości? Czy raz jeszcze można doświadczyć tego, co żyje już tylko w ludzkiej pamięci? Pamięć gromadzi wspomnienia, zarówno te, które chcielibyśmy zachować, jak też te, o których wolelibyśmy zapomnieć. Często także wbrew ludzkiej woli zaciera, zniekształca czy wręcz całkowicie zakrywa to, co dla nas cenne i ważne. Przeszłość, choć potocznie określa się ją jako to, co minione, co się wydarzyło, ale czego już nie ma, jako zbiór pewnych faktów, zapis utrwalonych w pamięci przeżyć, emocji i doznań, jest w istocie w dużym stopniu wytworem ludzkiego umysłu, wyobraźni, nieustannie zniekształcanym przez filtry rozmaitych późniejszych doświadczeń. Tym samym staje się rodzajem fantazmatu. Pragnienie jej powtórzenia wydaje się jednak naturalne,

${ }^{1}$ A. Berleant, Wrażliwość i zmysty. Estetyczna przemiana świata człowieka, przeł. S. Stankiewicz, redakcja naukowa K. Wilkoszewska, Kraków 2011, s. 45. 
zwłaszcza wówczas, gdy dotyczy doświadczeń aprobowanych, przeżyć wartościowanych pozytywnie i z rozmaitych powodów ważnych dla jednostki. Często oznacza to przecież powrót do młodości, dzieciństwa, a więc tych okresów ludzkiego życia, które wiążą się najczęściej z beztroską i radością. Jednak przeszłość i pamięć o niej mogą być nie tylko błogosławieństwem, lecz także przekleństwem; moga przynosić radość i ukojenie, ale również ożywiać miniony ból i cierpienia. Jaką więc przyjąć postawę wobec potencjalnej przynajmniej możliwości powtórzenia przeszłości? Taka decyzja może być nie lada wyzwaniem. Interesująca w tym kontekście wydaje się propozycja Fryderyka Nietzschego, który w Wiedzy radosnej rozważa taką oto alternatywę:

A gdyby tak pewnego dnia lub nocy jakiś demon wpełznął w twą najsamotniejszą samotność i rzekł ci: „życie to jak je teraz przeżywasz i przeżywałeś, będziesz musiał przeżywać raz jeszcze i niezliczone jeszcze razy; i nie będzie nic w nim nowego, tylko każdy ból i każda rozkosz, i każda myśl, i westchnienie, i wszystko niewymownie małe i wielkie twego życia wrócić ci musi, i wszystko w tym samym porządku i następstwie [...]”2.

Projekt niekończącego się powtórzenia wydaje się fascynujący i przerażający zarazem. Nietzsche rozważa dwie możliwe nań reakcje. Jedna z sugerowanych odpowiedzi na propozycję przedstawioną przez Nietzscheańskiego demona mówi o tym, że można go wykląc i „zgrzytać zębami”. W drugiej wersji wieść o możliwości powtórzenia może zostać przyjęta z radościa, a ów demon uznany za Boga przynoszącego boskie przesłanie. W przypadku pierwszej postawy - jak pisze Hanna Buczyńska-Garewicz - dochodzi do zniszczenia całej osobowości jednostki, którą to spotkało. Pojawia się tu bowiem niszczący ją resentyment. $\mathrm{W}$ drugim rozwiązaniu mamy do czynienia z uznaniem kolistości czasu wpisanego w ideę wiecznego powrotu. Aprobatywna postawa wobec tej koncepcji jest głębokim przeżyciem radykalnie zmieniającym jednostkę, która uzna ją za własną prawdę. Taki typ człowieka reprezentuje według Nietzschego egzystencję twórcza, afirmująca, której obca jest negacja i który wolny jest od resentymentu i nienawiści przez nią zrodzonych ${ }^{3}$. Wieczny powrót - zdaniem Piotra Augustyniaka jest wyrazem ekstatycznej i twórczej postawy wobec życia. Jawi się jako eksperyment, gra, ciagłe zaczynanie od nowa i konstytuowanie własnej tożsamości ${ }^{4}$. W idei wiecznego powrotu - najkrócej rzecz ujmując, chodzi więc - jak zauważa Bogdan Banasiak - „o taki sposób przeżywania chwili,

${ }^{2}$ F. Nietzsche, Wiedza radosna, przeł. L. Staff, Kraków 2004, s. 179.

${ }^{3}$ Zob. H. Buczyńska-Garewicz, Człowiek wobec losu, Kraków 2011, s. 126-127.

${ }^{4}$ Zob. P. Augustyniak, Wieczny powrót - między przymusem powtarzania a wola mocy, [w:] Boska radość powtórzenia. Idea wiecznego powrotu, red. M. Proszak, A. Szklarska, A. Żymełka, Kraków 2014, s. 131. 
by była ona akceptowana, by pragnąć i móc pragnąc jej powrotu, co chwilę tę naznacza stygmatem wieczności [...]"․ Przeszłość, teraźniejszość i przyszłość jawią się w świetle tej koncepcji jako jedność. Ujmując rzecz jeszcze inaczej, można powiedzieć słowami Gilles'a Deleuze’a, że przeszłość i przyszłość nie stanowią tu momentów różnych od obecnego, lecz są po prostu wymiarami teraźniejszości. Ta natomiast zawsze zdąża od przeszłości do przyszłości, ustanawiajacc je w czasie ${ }^{6}$. Idea wiecznego powrotu stwarza zatem szansę, by głęboko doświadczyć tej totalności czasu, by dzięki aprobatywnej postawie wobec minionych chwil, odczuć choć namiastkę wieczności.

Takie właśnie przychylne nastawienie do powtórzenia prezentuje narrator dzieła Sørena Kierkegaarda. Pragnie powtórzenia, lecz uznając jego możliwość, nie przyjmuje jej „na wiarę”. Szuka namacalnych dowodów, które mogłyby stanowić potwierdzenie, że powtórzenie istnieje. Osobiście chce raz jeszcze, dokładnie tak samo doświadczyć tego, co już kiedyś mu się przydarzyło. Johannes Sløk w komentarzu do Kierkegaardowskiego Powtórzenia stwierdza kategorycznie: „W estetycznym oglądzie świata powtórzenie jest błędem”. Dla estety bowiem, od logiki i ciagłości, ważniejsze jest poszukiwanie przyjemności, czegoś nowego, zaskakującego. A to, co zaskakuje, nie daje się powtórzyć. Zaskoczyć może tylko raz. Esteta pragnie chwil niezwykłych, porywajacych, ale „porywające przeżycie nie daje się powtórzyć ot tak, samo z siebie". Sam narrator Powtórzenia wyzna natomiast, że dialektyka powtórzenia jest łatwa, właśnie dlatego, że powtarza się coś, co już było (w innej sytuacji powtórzenie nie byłoby możliwe) i dlatego, że było, powtórzenie jawi się jako nowośćc ${ }^{9}$. W istocie jednak, stwierdzenie to wyraża równocześnie przekonanie, że powtórzenie jest niemożliwe. Jest bowiem czymś nowym w stosunku do tego, co przeminęło. Nie można powtórzyć uczuć, emocji i doznań związanych z konkretna sytuacją doświadczoną w przeszłości. Skoro powtórzenie przynosi nowość, to nie może pozostawać „tym samym”. Potwierdza to zreszta przeprowadzona przez narratora dzieła Sørena Kierkegaarda próba powtórzenia doświadczeń, odczuć i doznań, które towarzyszyły mu podczas pierwszej podróży do Berlina. Okazuje się bowiem, że niemal wszystko różni się od pierwowzoru, że przebiega i wygląda inaczej - i wizyta w berlińskim

${ }^{5}$ B. Banasiak, Wieczny powrót w myśli Friedricha Nietzschego - chaos czy ład, [w:] Boska radość powtórzenia..., s. 50.

${ }^{6}$ G. Deleuze, Różnica i powtórzenie, przeł. B. Banasiak, K. Matuszewski, Warszawa 1997, s. 118.

${ }^{7}$ J. Sløk, O pojęciu powtórzenia, [w:] S. Kierkegaard, Powtórzenie. Próba psychologii eksperymentalnej przez Constantina Constantinusa, przeł., wstępem i przypisami opatrzył B. Świderski, Warszawa 1992, s. 17.

${ }^{8}$ Tamże, s. 19.

${ }^{9}$ S. Kierkegaard, dz. cyt., s. 66. 
teatrze, i wygląd berlińskiego mieszkania. Jedynie powrót do znajomej restauracji jawi się jako „to samo: te same dowcipy, te same grzeczności, to samo podniecenie. Absolutnie ten sam lokal. Krótko mówiąc: to samo w tym samym. [...] Straszna myśl: tu powtórzenie jest możliwe" ${ }^{10}$. Niemniej, ogólna konstatacja z berlińskiej podróży narratora Powtórzenia jest następująca: „Nie potrzebujesz wcale ruszać się z miejsca, by przekonać się, że nie ma powtórzenia"11.

Przywołane stanowiska filozoficzne, choć w wielu punktach rozbieżne, ujawniają także pewne cechy wspólne i dlatego mogą stanowić spójną wykładnię interpretacyjna. Znamiennym aspektem łączącym na przykład ujęcie doświadczenia przeszłości w koncepcjach Nietzschego i Deleuze’a jest możliwość doznania totalności czasu, swoistego utożsamienia przeszłości z teraźniejszością i przyszłością. Kierkegaard z kolei, podobnie jak Nietzsche, akcentuje wpisane w naturę człowieka pragnienie powrotu do tego, co minęło. O ile jednak w ujęciu Kierkegaarda powtórzenie jest jednoznacznie niemożliwe, o tyle Nietzscheańska koncepcja wiecznego powrotu eksponuje przede wszystkim wagę nastawienia podmiotu do doświadczenia przeszłości. W proponowanej tu interpretacji Iwaszkiewiczowskich Panien $z$ Wilka wszystkie przywołane aspekty są niezmiernie ważne, ale tym, co rzeczywiście stanowi klucz dostępu do przeszłości Wiktora Rubena, jest ludzka zmysłowość, która pozwala wyeksponować estetyczny wymiar doświadczenia tego, co minęło.

Świat Wilka uruchamia bowiem cały wielowymiarowy potencjał percepcyjny bohatera. Zmysły umożliwiają mu dostęp do tego, co jest, ale pozwalają także na nowo zobaczyć przeszłość i choć w niewielkim stopniu ożywić minione przeżycia. Zmysłowość pobudzana przez rozmaite dźwięki, głosy, ciszę, zapachy, smaki, obrazy i towarzyszące im emocje konstytuuje rozległe spektrum estetycznych doznań bohatera. Różnorodne bodźce zewnętrzne pozwalają wydobyć z pamięci to, co już doświadczone, przeżyte kiedyśs, ale wywołują też nowe doznania dotyczące zarówno przeszłości, jak i teraźniejszości. Estetyczność stanowi bowiem splot pamięci, rozumienia i przede wszystkim aktywnej i intensywnej świadomości percepcyjnej ${ }^{12}$. Siła estetyczności polega w decydującej mierze na jej zdolności do wywoływania wyróżniającego się doświadczenia zmysłowego ${ }^{13}$. Właśnie dzięki szeroko pojętej zmysłowości odsyłającej do źródłowego dla doświadczenia estetycznego pojęcia aisthesis, doświadczenie to - za Mario Perniola - określić można jako akt witalny wypływający z najgłębszego i najbardziej ukrytego

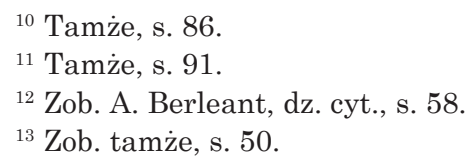


wymiaru ludzkiej egzystencji ${ }^{14}$. To zmysłowość jest przecież fundamentalnym dla człowieka źródłem dostępu do świata, do tego, co jest, ale także do tego, co było. W aisthesis właśnie - jak podkreśla Agnieszka Bandura człowiek odkrywa jedność świata i zarazem jego zróżnicowanie, dzięki niej także doświadczajacy podmiot może odzyskać własną samoświadomość i poczucie swej tożsamości. „Doświadczenie czy poznanie zmysłowe ma charakter procesu, niekończącej się drogi ku prawdzie rzeczywistości, jest otwarte na przyszłość, jak i na przeszłość, dynamicznie adaptuje się do teraźniejszości”"

Wiktor Ruben, wracając do miejsca, w którym nie był od piętnastu lat, podobnie jak bohater Kierkegaarda, prezentuje aprobatywna postawę wobec przeszłości, pragnie zanurzyć się raz jeszcze w minione doświadczenia młodości, ponownie doznać tego, co było, co bynajmniej nie oznacza, że pragnienie to się spełnia. Co więcej, prowadzi go także do niezwykle gorzkich refleksji. Ruben chce w miejscu odwiedzanym przed laty powtórzyć swa przeszłość nie tylko z pamięci, ale także w procesie powtórnego doświadczenia tego, co już było. Jednak konfrontacja tego, co zastaje i przeżywa w Wilku teraz, po latach, z zapamiętanymi obrazami, doznaniami, emocjami z przeszłości, podobnie, jak u Kierkegaarda, pozwala bohaterowi uświadomić sobie, że doświadczenia przeszłości nie można powtórzyć. Choć Ruben tego pragnie i początkowo nawet ma na to nadzieję, szybko odkrywa, że nie jest to możliwe. Bohater szukając w Wilku własnej przeszłości, szuka w istocie własnego ja, snuje refleksje nad czasem, przemijaniem, sensem własnej egzystencji. Dostrzega, że wraz z upływem ostatnich piętnastu lat wszystko uległo mniejszym bądź większym zmianom, ale przede wszystkim, że on sam inaczej postrzega i rozumie dziś to, czego doświadczył w Wilku kiedyś. Gdy przybywa, wydaje mu się początkowo, że nic się nie zmieniło ani wokół, ani w nim samym. Zaraz jednak uświadamia sobie, że to jedynie złudzenie. Zaczyna odkrywać zostawiona tu przeszłość na nowo i konfrontuje ją nie tylko z własną pamięcią czy może raczej z wyobrażeniami o niej, ale też z jej wizjami zapamiętanymi przez mieszkanki Wilka. Pewnych faktów nie pamięta wcale (np. tego, czy przed laty jeździł konno z Jola, jak ona twierdzi), ale są też takie zdarzenia, rozmowy, doświadczenia, które utkwiły w jego pamięci ze szczególną siłą (np. rozmowy z Kazią, nocne spotkania z Julcia). Z ich znaczenia i wagi dla swej późniejszej egzystencji zdał sobie sprawę dopiero po latach. Wróciwszy kolejny raz do Wilka, Ruben uświadomił so-

${ }^{14}$ Zob. M. Perniola, Estetyka wspótczesna. Panorama ogólna, przeł. P. Piotrowicz, E. Ranocchi, Kraków 2018, s. 21.

${ }^{15}$ A. Bandura, Aisthesis. Zmystowość i racjonalność w estetyce tradycyjnej i wspótczesnej, Kraków 2013, s. 118, 171-172. 
bie - mówiąc słowami Martina Heideggera - że „tego, co minęło, już nie ma, podczas gdy to, co było, wciąż roztacza swe treści”'16.

Iwaszkiewiczowski bohater w swych doświadczeniach teraźniejszych i przeszłych angażujących wszystkie jego zmysły, emocje i wyobraźnię, konstytuuje i jednocześnie potwierdza własną egzystencję. Pewność istnienia bowiem - jak pisała Barbara Skarga - dotyczy zawsze konkretnego pochłaniającego przeżycia ${ }^{17}$. Każde doświadczenie - mówiąc za Ewą Domańską - „odnosi się do działającej jaźni, do człowieka, który nie tylko jest zaangażowany w czynność, ale sam ją kształtuje" ${ }^{18}$. Dodać trzeba, że w tym kształtowaniu uczestniczy wyobraźnia, pamięć i właśnie rozmaite doznania zmysłowe, które nadaja estetyczny charakter minionym przeżyciom i tworzą wszystko to, co stanowi specyficzny, ulotny i niewyrażalny klimat konkretnego miejsca. Co więcej, w doświadczeniu estetycznym przeszłości nawet rzeczywista pamięć nie jest konieczna, na co zwraca uwagę Teresa Pękala. Ważniejsze jest właśnie pobudzenie zmysłów uruchamiających wyobraźnię i wywołujących rozmaite skojarzenia związane z danym miejscem ${ }^{19}$.

Wiktor Ruben, od momentu przyjazdu tropi i drobiazgowo rejestruje wszelkie zmiany dostrzeżone już w samym otoczeniu. Idąc ze stacji, rozpoznaje pod stopami nawet nierówności gruntu, ale największe wrażenie wywiera na nim nieoczekiwany widok lasu, który przed laty był zaledwie niewielkim zagajnikiem. Ten las jest obecnie dla bohatera szczególnym znakiem przemijania, ulotności, niestałości: „[...] całe życie upłynnione w mrówczych, nikomu niepotrzebnych zajęciach, nie dało Wiktorowi takiego poczucia minionego czasu, co widok tego lasu w miejscu dawnego zagajnika"20. Zamiast niewielkich delikatnych roślinek Ruben zastaje duże czarne drzewa. Bohater zatrzymuje się, wzdycha, a pochyliwszy się, dostrzega mały czarny słupek graniczny. Dobrze go pamięta, bo do tego właśnie miejsca odprowadziła go przed piętnastu laty Jola w dniu wyjazdu z Wilka. Stąd też będzie wyjeżdżał i tym razem.

Jednak nie tylko ów ogromny las, ale także inne elementy krajobrazu wyznaczające drogę ze stacji do folwarku Wilko pamięta bardzo dokładnie. Olbrzymie białodrzewy, parów, wierzby, zagajnik wywołuja rozmaite wspomnienia, prowadza do nostalgicznej refleksji nad upływem czasu i przemi-

${ }^{16}$ M. Heidegger, Grundbergriffe, Frankfurt am Main 1981, s. 86. Cyt. za: B. Skarga, Kwintet metafizyczny, Kraków 2005, s. 73.

${ }^{17}$ Zob. B. Skarga, Tożsamość i różnica. Eseje metafizyczne, Kraków 2009, s. 259.

${ }^{18}$ E. Domańska, Mikrohistorie. Spotkania $w$ międzyświatach. Wydanie drugie uzupełnione i uaktualnione, Poznań 2005, s. 139.

${ }^{19}$ Zob. T. Pękala, Estetyczne konteksty doświadczenia przeszłości, Lublin 2013, s. 212-213.

${ }^{20}$ J. Iwaszkiewicz, Panny z Wilka, [w:] Opowiadania, Warszawa 1995, s. 7. Dalej oznaczam jako PW. Wszystkie cytaty i odwołania do tego utworu lokalizuję bezpośrednio w tekście, podając $\mathrm{w}$ nawiasie wraz $\mathrm{z}$ numerem strony. 
janiem. Jednocześnie, jakby wbrew temu poczuciu ulotności i niestałości ludzkiej egzystencji obserwowane pola uprawne, zasiane jak przed laty, wywołuja u bohatera wrażenie zatrzymania czasu. Wydaje mu się przez moment, że jednak nic się tutaj nie zmieniło, że nawet on sam się nie zmienił i jest wciąż młody, że minione piętnaście lat nie ma znaczenia i że nie pora na rozmyślanie o starości. Można zatem stwierdzić, że powrót do Wilka jest dla Rubena także powrotem do krajobrazu, który - mówiąc za Beata Frydryczak - ukazuje się bohaterowi nie tylko wizualnie, ale jawi mu się w doświadczeniu wielozmysłowym, angażując jednocześnie jego emocje, uruchamiając wspomnienia tego, co minione i projektowane wyobrażenia tego, co potencjalnie może zastać w Wilku. To wielozmysłowe zaangażowanie w krajobraz streścić można w formule „bycia w krajobrazie”, która w odróżnieniu od „bycia wobec krajobrazu” wymaga właśnie zaangażowania i aktywności wszystkich zmysłów ${ }^{21}$.

Do domu „panien z Wilka” bohater wchodzi pewnie, jak dawniej, jakby wcale nie było owych ostatnich piętnastu lat. Wzrokiem ogarnia przedpokój, odnotowując zmianę mebli, ale machinalnie w dawnym miejscu odwiesza teczkę, płaszcz i kapelusz. Gdy usłyszy dochodzące z wnętrza głosy, wydadzą mu się one „łudząco podobne do tych, jakie słychiwał tu dawniej” (PW, s. 11). Pozwoli to bohaterowi odnieść wrażenie, że czas się zatrzymał, będzie się nawet łudził, że zaraz pojawi się w drzwiach malutka Tunia, która oznajmi pozostałym domownikom o jego przyjeździe. I rzeczywiście wita go najmłodsza z sióstr, ale to dorosła już dziś kobieta. W czasie tego pierwszego po latach spotkania bohater niezwykle uważnie obserwuje każda z „panien z Wilka” i przypomina sobie, jak każda z nich zapamiętał, jak widział kiedyś, jak spędzał z nimi czas i drobiazgowo odnotowuje, jak wilkowskie panny jawią mu się teraz. Ruben rejestruje rozmaite szczegóły wyglądu, zachowania, gestykulacji, mimiki oraz własne doznania wywoływane przez te spostrzeżenia. Gdy nagle znajduje się w otoczeniu wszystkich zamieszkujacych Wilko kobiet, od razu rozpoznaje jedynie Jolę, zapamiętaną jako najładniejszą z sióstr, Julcię natomiast, z której twarza, postacia, ale też głosem zawsze kojarzyło mu się to miejsce, identyfikuje właśnie po głosie, niskim i pięknym, pamiętanym potem przez długie lata. Sama Julcia jednak wydaje się dziś Rubenowi kimś całkowicie innym. „Tamta Julcia była smukła, zgrabna, żywa, nieopanowana i mająca jakieś dziwne porywy" (PW, s. 16). Po latach postrzega ją jako dostojna, miła, poważną damę o zimnych niebieskich oczach i pięknej twarzy, ale zupełnie obca.

${ }^{21}$ Zob. B. Frydryczak, O doświadczeniu bycia w krajobrazie, [w:] Między integracja i rozproszeniem. Doświadczenie estetyczne w kontekstach nowoczesności, red. I. Lorenc, M. Rychter, M. Salwa, Warszawa 2018, s. 146. 
Jednak to właśnie z Julcią wiąże się jedno z najsilniejszych wspomnień Rubena związanych z jego pobytem w Wilku przed laty. Za Barbara Skarga ten rodzaj wspomnień można określić jako cymelia, które choć moga być zarówno najcenniejsze, najdroższe, ale też najstraszniejsze, to zawsze pozostaja „skarbem intymności” ${ }^{22}$. Dla bohatera taki szczególny charakter miała erotyczna relacja z Julcia, relacja milcząca, nigdy niewypowiedziana, „niema komedia niemożliwego snu” (PW, s. 19), bo tylko cisza otwiera na to, co pozazmysłowe i pozaempiryczne. Wspomnienie tych kilku erotycznych spotkań z Julcią jawi się Rubenowi niczym „zetknięcie z czymśs nieskończenie pięknym i pachnącym" (PW, s. 19), ale jednocześnie jako doświadczenie, o którym trzeba milczeć, by w słowach nie zniszczyć wspomnienia tego cudownego doznania, które już nigdy potem się nie powtórzyło.

Zapamiętane wizje czterech wspólnych nocy sprzed wielu lat nie opuszczały Wiktora już przez resztę życia; nigdy wcześniej ani nigdy później nie doświadczył czegoś podobnego. I chociaż powrót do Wilka po piętnastu latach okazał się w jakimś sensie także powrotem do dawnego romansu, to $\mathrm{w}$ istocie było to już zupełnie inne doznanie. Doświadczenie dotyku sprzed lat okazuje się niemożliwe do powtórzenia; tamto było piękniejsze od kwiatu (PW, s. 55), a dziś dotyk skóry Julci nie budzi już w bohaterze dawnego uniesienia. Przeciwnie, wydaje mu się czymś tak banalnym, że aż go ów fakt przeraża. „Nic z dawnego nieprawdopodobnego dreszczu, nic z tego milczenia żądzy, która paraliżowała mu język. Julcia była taką samą kobietą jak tysiące innych" (PW, s. 55). Niczym esteta, o którym pisał przywoływany uprzednio Johannes Sløk, Iwaszkiewiczowski bohater zdaje sobie sprawę, że to, co było niezwykłe i zaskakujące kiedyś, dziś już nie może zostać powtórzone. Pamięć nie jest bowiem zdolna do przechowywania wspomnień w „nienaruszonym” stanie - zauważa Buczyńska-Garewicz. Nie mogą one być „wiernym” powtórzeniem ich pierwotnego sensu, bo funkcjonują w ciagle żywej świadomości, która sytuuje je w nieustannie zmieniającym się horyzoncie nowych przeżyć i doświadczeńn ${ }^{23}$.

I teraz, po latach, bohater - choć początkowo miał nadzieję na wyjaśnienie tych niemych erotycznych spotkań sprzed lat i pragną dowiedzieć się, co one znaczyły dla Julci i czy ona również je wspomina - uświadamia sobie, że nic już nie może zostać wyjaśnione, że wszystko zostało zamknięte w przeszłości. „Pytania i niedoszłe rozmowy utonęły na zawsze, nigdy sobie o tym nie powiedzą i jak wtedy udawali, że śpia, tak teraz muszą udawać, że nie pamiętają" (PW, s. 20). I choć Wiktorowi wydaje się, że bardzo dobrze zapamiętał te doświadczenia, to - mówiąc za Walterem Benjaminem - jako

${ }^{22}$ B. Skarga, Tożsamość i różnica..., s. 322.

${ }^{23}$ H. Buczyńska-Garewicz, Metafizyczne rozważania o czasie, Kraków 2003, s. 73. 
przeżyte, zostały one zamknięte w „sferze przeżywania”, do której nie ma już teraz dostępu. Natomiast raz po raz przypominane, są wciąż na nowo doświadczane, a tym samym wydaja się „pozbawione ograniczeń” ${ }^{24}$.

Drugim niezwykle głębokim dla Rubena doświadczeniem związanym z dawnym pobytem w Wilku był widok nagiej Feli nad stawem. Wracając z polowania na kaczki, bohater zaszedł na łąkę, nad staw. Tam niespodziewanie ujrzał Felę. Całkiem naga stała do niego tyłem i rozczesywała włosy. Naprzeciw niej siedziała ubrana w czerwoną suknię Jola. Scena ta ukazała się bohaterowi niczym kompozycja malarska. Blask zachodzącego już słońca oświetlił białe ciało dziewczyny i suknię jej siostry. Gdy Fela spostrzegła obecność Wiktora, początkowo zaczęła z nim spokojnie rozmawiać, zapominając, że jest rozebrana. Gdy sobie to jednak uświadomiła, w popłochu skryła się za Jola, a Wiktor tymczasem czekał w wierzbowych zaroślach aż się ubierze. Raz po raz zamykał oczy, a pod powiekami miał wciąż obraz pięknej, nagiej panny oświetlonej słonecznym blaskiem. Tej wizji towarzyszył wówczas intensywny zapach goryczy mokrych lasów, który zapadł bohaterowi głęboko w pamięć i niezmiennie, także po latach, przywodzi mu na myśl tę niezapomniana scenę. W tym szczególnym przeżyciu to właśnie wrażenia olfaktoryczne okazują się bardzo istotne. Podkreślają one nie tylko specyfikę miejsca, tworząc jego terytorialną tożsamość, o czym pisała Elżbieta Rybicka ${ }^{25}$, lecz przede wszystkim aktywizując pamięć, sprawiaja, że to niezwykłe wspomnienie konkretyzuje się w postaci wizualnego wyobrażenia.

Obraz nagiej Feli sprzed lat zyskuje dla bohatera szczególne znaczenie, gdy przybywszy po latach do Wilka, dowiaduje się, że Fela zmarła przed ponad dekada. Jest tym niezwykle poruszony i przygnębiony. Jej zaniedbany grób uświadamia mu, że dziśs nikt w Wilku o niej nie pamięta. „Zapomnieli o jej istnieniu nawet, a któż by dopiero pamiętał jej ciało oświetlone zachodzacym słońcem. On sam tylko na świecie ma taką tajemnicę..." (PW, s. 35). Dziś to najmłodsza z sióstr, Tunia, „w uśmiechu, roześmianiu się, odwróceniu lub pochyleniu głowy" (PW, s. 51) najbardziej przypomina Wiktorowi nieżyjąca już Felę. Obrazy obu sióstr zlewają mu się, zacierając granicę życia i śmierci, przeszłości i teraźniejszości. Tunia nie pamiętała Wiktora sprzed piętnastu laty. Była wówczas małym dzieckiem. Dlatego dziś tylko ona sprawia, że Ruben uwalnia się od wspomnień i znów czuje się młodo, bo tylko dla niej jest kimś nowym. Dzięki niej przeszłość jawi się Wiktorowi jako palimpsest, jakby na moment w drobnych ruchach i gestach Tuni ukazała mu się Fela;

${ }^{24}$ W. Benjamin, Do wizerunku Prousta, przeł. J. Sikorski, [w:] tegoż, Twórca jako wytwórca, Poznań 1975, s. 279.

${ }^{25}$ E. Rybicka, Geopoetyka. Przestrzeń i miejsce we wspótczesnych teoriach i praktykach literackich, Kraków 2014, s. 362. 
bohater przedziera się dzięki temu przez warstwy czasu, by w najmłodszej wilkowskiej pannie odnaleźć namiastkę przeszłych doświadczeń. Rozmowy prowadzone z Fela przed laty, wspólnie odbyte spacery, teraz, dzięki Tuni, jawią mu się jako swoisty głos zza grobu. Osobowość, mimika, sposób mówienia i poruszania się najmłodszej z sióstr sprawiają, że Wiktor odzyskuje chociaż namiastkę tego, co bezpowrotnie minęło.

„Uobecniając przeszłość w estetycznym przeżyciu włączamy ją w wymiar czasoprzestrzeni, osłabiamy tym samym jej czasowość. Wektor czasu traci w przeżyciach estetycznych jasne ukierunkowanie i jak strzałka kompasu pod wpływem sił magnetycznych, gubi orientację" ${ }^{26}$. Czas jawi się jako kolisty, przeszłość, przyszłość i teraźniejszość nakładają się na siebie. Wówczas człowiek zyskuje własną tożsamość - jak pisała Buczyńska-Garewicz - jawi się jako całość niepodzielona na pojedyncze chwile, ukazuje się jako egzystencja, wobec której pytanie o pragnienie powtórzenia przestaje być niedorzecznością i jest jak najbardziej uprawomocnione ${ }^{27}$. Bohaterowi Iwaszkiewiczowskiego opowiadania przez moment wydaje się właśnie, że może pokonać czas, że udało mu się go zawrócić, że znów jest tam, gdzie był przed piętnastu laty i że na nowo może wszystko rozważyć, raz jeszcze dokonać wyboru. „Teraz dopiero rozumiał, co było urokiem tamtych dwóch lat i dlaczego tak łatwo mu się one uplastyczniły. To był nieuświadomiony młodzieńczy erotyzm, jaki się rozlewał w powietrzu naokoło sześciu dziewcząt ładnych i przyjemnych. To było to, co i dla nich miało wówczas znaczenie i dlatego one tak dobrze o nim pamiętały. Powtarzały mu najdrobniejsze jego słowa, czyny [...]”. (PW, s. 22). Pamięć o własnych działaniach, doświadczeniach, doznaniach, myślach i przeżyciach - co podkreśla Barbara Skarga - pomaga pokonać czas, a tym samym zmiany, jakim człowiek podlega. Potwierdza jednocześnie ludzką tożsamość i utwierdza w przekonaniu o ciagłości własnego trwania ${ }^{28}$.

Pierwszy pobyt w Wilku Ruben traktuje po latach jako swoisty wstęp, zapowiedź wydarzeń, które dopiero później miałyby zyskać swój dalszy ciag, spełnienie. Teraz wnioskuje, że wyjaśnienie i rozwiązanie różnych spraw i sytuacji powstałych tam przed laty, podświadomie odkładał, czując, że kiedyś tu wróci, „że będzie znowu na podwieczorku w Wilku” (PW, s. 22), ale dostrzega jednak, że wszystko zupełnie się zmieniło. Szybko uświadamia sobie, że to złudna nadzieja, by odzyskać przeszłość, ponownie przeżyć to, co się tu kiedyś wydarzyło, że czas miniony pozostał na zawsze zamknięty, a wraz z nim wszystko, czego wówczas doświadczył, co przeżył. Nic już nie będzie powtórzone. Powtórzenie ginie bowiem - jak pisał Deleuze - w chwili,

${ }^{26}$ T. Pękala, Estetyczne konteksty..., s. 172.

${ }^{27}$ H. Buczyńska-Garewicz, Człowiek..., s. 126.

${ }^{28}$ Zob. B. Skarga, Tożsamość i różnica..., s. 302. 
gdy powstaje ${ }^{29}$. Dostęp do tych przeżyć i doświadczeń z przeszłości umożliwia jedynie pamięć. Pamięć zawodna, niedoskonała, fragmentaryczna...

Przyjmując za Stanisławem Ossowskim, że: „Do przeszłych wydarzeń można się nastawić bądź «przyszłościowo» (gdy naprawiamy przeszłość, gdy myślimy o skutkach wydarzeń), bądź «aktualnie» (gdy pogrążamy się biernie w wizjach przeszłości” ${ }^{30}$, trzeba zadać pytanie, czy można też inaczej. Wydaje się, że Wiktor Ruben ani nie naprawia przeszłości, ani nie pogrąża się w jej wizjach. Jeśli te wizje przywołuje, to po to, by rozpoznać przeszłość $\mathrm{w}$ tym, co jest teraz i konfrontować z bieżącymi doświadczeniami obrazy, sytuacje, doznania wydobyte z własnej pamięci, ale też z pamięci innych. W ten sposób ożywia przeszłość, ale jednocześnie ją przekształca, czy raczej zniekształca, modyfikuje własne o niej wyobrażenia. Rozmaite obrazy przeszłości i teraźniejszości nakładają się na siebie niczym klisze pamięci w teatrze Tadeusza Kantora.

Szczególnie znamienne przykłady w tym zakresie stanowia sytuacje, w których w świadomości bohatera kumulują się obrazy z pierwszego pobytu w Wilku i obrazy z czasu pierwszej wojny światowej, w której uczestniczył. W kontekście projekcji tych wizji z różnych porządków czasowych ważne jest także to, czego bohater doświadcza obecnie. Znaczenie tu mają zarówno stany psychiczne, jak i somatyczne. Ruben przyznaje, że np. kiedy jest zmęczony, te dawne obrazy wynurzają się na powierzchnię jego świadomości, utrzymują na niej przez moment, a następnie toną w jej głębi, by po chwili pojawić się znowu, albo ustapić pola innym. I tak powraca na przykład kilkukrotnie widok martwego żołnierza, „pejzaż” na Murmanie czy wspomnienie z wyprawy kijowskiej, podczas której zdarzyło się Wiktorowi spać w łóżku „na którym przed chwilą zakłuto Żyda” (PW, s. 33). Do dziś bohater pamięta mdły zapach krwi, ale też fakt, że potrzeba snu była wówczas silniejsza od wszystkiego. Wspomnienie tego doświadczenia ma niezwykle intensywny, somatyczny charakter, podobnie, jak inny powracający też w namacalnym, fizykalnym niemal doznaniu obraz martwego ciała żołnierza. Podczas popołudniowych drzemek u wujostwa w Rożkach mieszają się Rubenowi doznania i wyobrażenia tego, co dopiero przeżyte $\mathrm{z}$ dawnymi wspomnieniami i wizjami z przeszłości. Bohater wówczas własne ciało odczuwał jako obce, zewnętrzne wobec siebie. Raz było to ciało kobiece, innym razem długo nie dawało się określić, co sprawiało, że sen stawał się bardzo męczący. I właśnie to nieokreślone ciało raz udało się bohaterowi rozpoznać jako zwłoki zabitego żołnierza. Jednak doznanie to nie sprawiło mu jakiejkolwiek przykrości, a wręcz przeciwnie; jego przyjemne ciepło wy-

${ }^{29}$ G. Deleuze, dz. cyt., s. 380.

${ }^{30} \mathrm{~S}$. Ossowski, Wybór pism estetycznych. Wprowadzenie, wybór i opracowanie B. Dziemidok, Kraków 2004, s. 79. 
dało się Rubenowi bliskie doznaniu erotycznemu. I znowu raz odczuwał je jako własne, raz jako obce, oddzielone od niego „nieprzenikniona przepaścią męczącej osobności” (PW, s. 57). Za Barbara Skargą powiedzieć więc można, że ciało, będące podstawą tożsamości, okazuje się często jednocześnie tym, co tę tożsamość burzy. Cielesność pełna jest bowiem ambiwalencji, w wyniku której można tę własną tożsamość utwierdzić, ale można też ją utracić. Bez względu na wszystko jednak, wszelkie somatyczne właściwości rozmaitych doświadczeń sa jedyne i niepowtarzalne, jednostkowe i nieredukowalne do jakichkolwiek opisów z zewnątrz ${ }^{31}$. Są też niezwykle nietrwałe i ulotne, gdyż najczęściej jawią się one - jak zauważa Richard Shusterman - jako momentalne wrażenia nieprzynależne stabilnym obiektom, a sprawa komplikuje się jeszcze bardziej, gdy odczucia percepcyjne doznawane sa somatycznie przy wyłączeniu pełnej świadomości, np. właśnie we śnie ${ }^{32}$.

Wydaje się, że wywoływane z pamięci obrazy dzięki rozmaitym bodźcom zmysłowym jawią się Rubenowi jako ślad w rozumieniu, jakie zaproponowała autorka Tercetu metafizycznego. „To znak fenomenu z przeszłości, czegoś, co wydarzyło się, minęło, pozostawiło jednak swoją pieczęé"33. Ślad można widzieć zatem jako znak trwania w pamięci, we wspomnieniu tego, co było, ale też może jawić się on jako to, co nieobecne, pozostałość tego, co jest zaledwie świadectwem jakiejś minionej, ale niemożliwej do powtórnego przywołania przeszłości. Ślad, jak pisze Mateusz Bednarkiewicz, świadczy jednocześnie o nieobecności (tego, co już było) i oddaleniu (podmiotu od jego przeszłości). Jest tym samym znakiem upływu czasu i przemijania ${ }^{34}$.

Wizyta w Wilku to dla Iwaszkiewiczowskiego bohatera także pretekst do spojrzenia na całe swoje dotychczasowe życie, okazja do podjęcia refleksji nad dawnymi wyborami, możliwościami i marzeniami, ale również do postawienia diagnozy teraźniejszości. Dopiero wróciwszy po latach do tego miejsca, Ruben uświadamia sobie, że jego życie wcale nie jest takie, jakiego pragnął w młodości, dopiero tu zdaje sobie sprawę, że przed laty podkochiwał się w Joli, dowiaduje się także, że prawdziwie szczerze kochała go Kazia, czego nie był wówczas świadomy. Z niedowierzaniem odkrywa, że wszystkim „pannom z Wilka” wydawał się niezmiernie interesujący i bardzo się podobał, a to z kolei prowadzi do bolesnej refleksji, że sam nigdy nikogo nie kochał do szaleństwa. „W ogóle był przerażony przepaściami swej owoczesnej nieświadomości, ale i teraz widział, że nie pojmował wielu rzeczy jak inni,

${ }^{31}$ B. Skarga, Tożsamość i różnica..., s. 301-302.

${ }^{32}$ Zob. R. Shusterman, Myślenie ciała. Eseje z zakresu somaestetyki, przeł. P. Poniatowska, Warszawa 2016, s. 285.

${ }^{33}$ B. Skarga, Ślad i obecność, Warszawa 2002, s. 76.

${ }^{34}$ Zob. M. Bednarkiewicz, „Po przekroczeniu progu”- szkic z „estetyki śladu”, [w:] Między integracjq i rozproszeniem..., s. 337. 
że był osobniejszy, niż był [...]" (PW, s. 49). Tutaj uświadomił sobie nicość wszystkich swoich dotychczasowych przeżyć, ale też fakt, że jego egzystencja nie jest w jakikolwiek sposób wyjątkowa, że żyje jak wszyscy, a przecież nie tego pragnął. Ta podróż do przeszłości wzbudziła w bohaterze ogromną tęsknotę za tym, co minęło, za młodością i niespełnioną miłościa.

Choć sporadycznie, obok tych pesymistycznych refleksji, pojawiają się też te optymistyczne (dotyczące wiary w to, że jeszcze nie wszystko stracone, że młodość jeszcze nie przeminęła i że nadal istnieje szansa, by odmienić swą egzystencję i zaczać życie od nowa), to w istocie nad wszelkimi przeżyciami, wspomnieniami Wiktora rozpościera się ogromny żal za miniona przeszłościa. Żal ów ogarnia bohatera ze szczególna siła tuż przed wyjazdem. Ruben doznaje wrażenia, jakby wszystko to, co wydarzyło się tu przed piętnastu laty, dokonało się bez jego udziału. Piętnaście lat zlewa mu się nagle w jedną monotonną całość, minione lata wydają się łudząco do siebie podobne, jednostajne, rok nie różni się od roku. Przeszłość jawi mu się jako coś nieodwołalnego ${ }^{35}$. Bohater w przypływie żalu nad minionym czasem uświadamia sobie, że piętnaście razy mógł wrócić do Wilka, a jednak ani razu tego nie uczynił.

Wanitatywna metafora prochu, za pomoca której bohater opisuje ostatnie piętnaście lat swej egzystencji, najdobitniej wyraża ową tęsknotę za utracona przeszłościa, a przede wszystkim za niewykorzystanymi możliwościami, które wówczas rysowały się przed nim. Tę sytuację Ruben podsumowuje gorzkimi słowami: „Wielki to grzech nie umieć spostrzec własnego szczęścia" (PW, s. 71) i teraz, we wspomnieniach, dokonuje rozpoznania tego, co minione. „Fenomen rozpoznania odsyła [...] do zagadki wspomnienia jako obecności tego, co nieobecne, a uprzednio napotkane pisze Paul Ricoeur - i dodaje, że „ów cud rozpoznania polega na tym, że teraźniejszość zostaje spowita innością tego, co minione" ${ }^{36}$. Nie wydaje się jednak, że Ruben - mówiąc za Ryszardem Przybylskim - w przeszłości szuka pocieszenia i zbawienia ${ }^{37}$. Raczej - jak sugeruje Helena Zaworska Iwaszkiewiczowski bohater próbuje nadać sens swojej egzystencji ${ }^{38}$. Można dodać, że pragnie także zdefiniować swoją tożsamość, rozpoznać siebie samego i teraz, i w przeszłości, dookreślić swój los. W perspektywie teraźniejszości przeszłość zyskuje nowe znaczenia, ale to, co minione, kształtuje także teraźniejsze przeżycia bohatera, który w Wilku staje twarzą w twarz

${ }^{35}$ Zob. M. Merleau-Ponty, Fenomenologia percepcji, przeł. M. Kowalska, J. Migasiński, Warszawa 2001, s. 440.

${ }^{36}$ P. Ricoeur, Pamięć, historia, zapomnienie, przeł. J. Margański, Kraków 2007, s. 56.

${ }^{37}$ Zob. R. Przybylski, Eros i Tanatos. Proza Jarosława Iwaszkiewicza 1916-1938, Warszawa 1970, s. 171.

${ }^{38}$ H. Zaworska, Opowiadania Jarostawa Iwaszkiewicza, Warszawa 1985, s. 24-25. 
z własną przeszłością, ale również z kobietami, które wówczas w rozmaity sposób tę jego przeszłość współtworzyły i - nawet jeśli nieświadomie - to znacząco wpłynęły na jego los, a także na to, jak Wiktor widzi własną przeszłość dziś, a w jej perspektywie również swoje obecne życie. Podczas kolejnego pobytu w Wilku w Rubenie - pisze Józef Majewski - zachodzi głęboka wewnętrzna przemiana, „a wszystko dokonuje się w obłoku koloru białego". Wielokrotnie powracajacca w Iwaszkiewiczowskim opowiadaniu biel odnosi się do przejawów życia, słońca, blasku, słodyczy, radości, piękna, ale jednocześnie oznacza tu także śmierć, nicość, zwiędłe kwiaty, trupi zapach, nieruchomość, martwość... ${ }^{39} \mathrm{Tu}$ w istocie uświadamia sobie bohater nierozłączny związek życia i śmierci, nieuchronność upływu czasu, przemijania.

Każdy zachowany we wspomnieniach fragment przeżytej przeszłości mówiąc za Merleau-Pontym - jest jedynie okazją do pomyślenia o niej, lecz sam nie daje się rozpoznać jako przeszły, bo niemożliwy jest już bezpośredni kontakt z tym, co minione ${ }^{40}$. Co więcej, wraz z upływem czasu, kim innym staje się także doświadczający przeszłości podmiot i dlatego powtórzenie jak pisał Gilles Deleuze - zawsze musi pozostać naznaczone różnica ${ }^{41}$. Powtórzenie doskonałe byłoby możliwe jedynie wówczas, gdyby dało się - mówiąc słowami Tadeusza Kantora - ścisnąć czas:

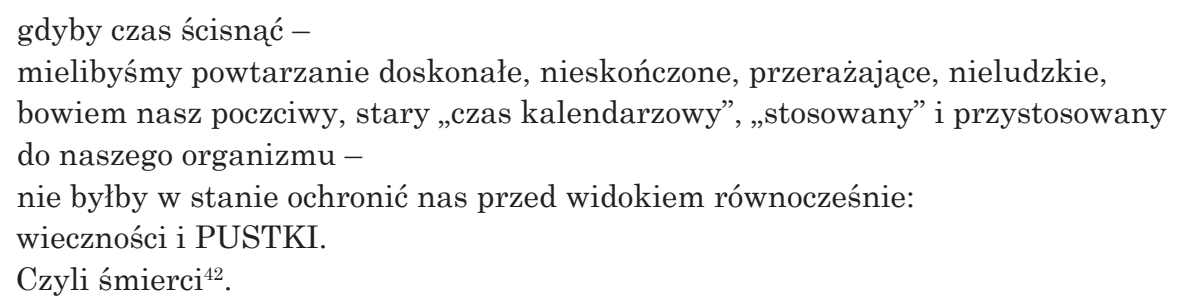

Ruben, paradoksalnie, podczas kolejnego pobytu w Wilku właśnie tę pustkę dostrzega, choć zarazem boleśnie przekonuje się, że nic nie może zostać powtórzone; nie można powtórzyć żadnych wyborów z przeszłości, podjać raz jeszcze poczynionych kiedyś decyzji, powtórzyć doznań, emocji, ujrzeć tych samych obrazów. Dostępne są one jedynie jako okruchy, fragmenty, ułomki, wizje zawsze niedoskonałe, zniekształcane we wspomnieniach warunkowanych przecież niezmiennie przez całe spektrum rozmaitych doznań zmysłowych. Iwaszkiewiczowski bohater opuszczając Wilko,

${ }^{39}$ J. Majewski, Fuga przemijania. Stowo o eschatologii Jarosława Iwaszkiewicza, Gdańsk 2014, s. 13, 25-26.

${ }^{40}$ Zob. M. Merleau-Ponty, dz. cyt., s. 434-435.

${ }^{41}$ Zob. G. Deleuze, dz. cyt., s. 56.

${ }^{42}$ T. Kantor, Iluzja i powtarzanie, [w:] tegoż, Teatr Śmierci. Teksty z lat 1975-1984, t. 2, wybór i opracowanie K. Pleśniarowicz, Wrocław-Kraków 2004, s. 342. 
nie ma już żadnych złudzeń, że czas doświadczony tu przed piętnastu laty nieuchronnie przeminął. Estetyczne doświadczenie przeszłości okazuje się $\mathrm{w}$ istocie egzystencjalnym doświadczeniem $\mathrm{czasu}^{43}$.

\section{BIBLIOGRAFIA PODMIOTOWA}

Iwaszkiewicz J., Panny z Wilka, [w:] Opowiadania, Warszawa 1995.

\section{BIBLIOGRAFIA PRZEDMIOTOWA}

Augustyniak P., Wieczny powrót - między przymusem powtarzania a wola mocy, [w:] Boska radość powtórzenia. Idea wiecznego powrotu, red. M. Proszak, A. Szklarska, A. Żymełka, Kraków 2014.

Banasiak B., Wieczny powrót w myśli Friedricha Nietzschego - chaos czy tad, [w:] Boska radość powtórzenia. Idea wiecznego powrotu, red. M. Proszak, A. Szklarska, A. Żymełka, Kraków 2014.

Bandura A., Aisthesis. Zmystowość i racjonalność w estetyce tradycyjnej i wspótczesnej, Kraków 2013.

Bednarkiewicz M., „Po przekroczeniu progu” - szkic z „estetyki śladu”, [w:] Między integracja $i$ rozproszeniem. Doświadczenie estetyczne w kontekstach nowoczesności, red. I. Lorenc, M. Rychter, M. Salwa, Warszawa 2018.

Benjamin W., Do wizerunku Prousta, przeł. J. Sikorski, [w:] tegoż, Twórca jako wytwórca, Poznań 1975.

Berleant A., Wrażliwość i zmysty. Estetyczna przemiana świata człowieka, przeł. S. Stankiewicz, redakcja naukowa K. Wilkoszewska, Kraków 2011.

Buczyńska-Garewicz H., Człowiek wobec losu, Kraków 2011.

Buczyńska-Garewicz H., Metafizyczne rozważania o czasie, Kraków 2003.

Deleuze G., Różnica i powtórzenie, przeł. B. Banasiak, K. Matuszewski, Warszawa 1997.

Domańska E., Mikrohistorie. Spotkania w międzyświatach. Wydanie drugie uzupełnione i uaktualnione, Poznań 2005.

Frydryczak B., O doświadczeniu bycia $w$ krajobrazie, [w:] Między integracja i rozproszeniem. Doświadczenie estetyczne w kontekstach nowoczesności, red. I. Lorenc, M. Rychter, M. Salwa, Warszawa 2018.

Heidegger M., Grundbergriffe, Frankfurt am Main 1981.

Kantor T., Iluzja i powtarzanie, [w:] T. Kantor, Teatr Śmierci. Teksty z lat 1975-1984, t. 2, wybór i opracowanie K. Pleśniarowicz, Wrocław-Kraków 2004.

Kierkegaard S., Powtórzenie. Próba psychologii eksperymentalnej przez Constantina Constantinusa, przeł., wstępem i przypisami opatrzył B. Świderski, Warszawa 1992.

Majewski J., Fuga przemijania. Stowo o eschatologii Jarosława Iwaszkiewicza, Gdańsk 2014.

${ }^{43}$ Zob. T. Pękala, Czas miniony jako doświadczenie przestrzeni, [w:] Czas przestrzeni, red. K. Wilkoszewska, Kraków 2008, s. 343. 
Merleau-Ponty M., Fenomenologia percepcji, przeł. M. Kowalska, J. Migasiński, Warszawa 2001.

Nietzsche F., Wiedza radosna, przeł. L. Staff, Kraków 2004.

Ossowski S., Wybór pism estetycznych. Wprowadzenie, wybór i opracowanie B. Dziemidok, Kraków 2004.

Perniola M., Estetyka wspótczesna. Panorama ogólna, przeł. P. Piotrowicz, E. Ranocchi, Kraków 2018.

Pękala T., Czas miniony jako doświadczenie przestrzeni, [w:] Czas przestrzeni, red. K. Wilkoszewska, Kraków 2008.

Pękala T., Estetyczne konteksty doświadczenia przeszłości, Lublin 2013.

Przybylski R., Eros i Tanatos. Proza Jarostawa Iwaszkiewicza 1916-1938, Warszawa 1970.

Ricoeur P., Pamięć, historia, zapomnienie, przeł. J. Margański, Kraków 2007.

Rybicka E., Geopoetyka. Przestrzeń i miejsce we wspótczesnych teoriach i praktykach literackich, Kraków 2014.

Shusterman R., Myślenie ciała. Eseje z zakresu somaestetyki, przeł. P. Poniatowska, Warszawa 2016.

Skarga B., Kwintet metafizyczny, Kraków 2005.

Skarga B., Ślad i obecność, Warszawa 2002.

Skarga B., Tożsamość i różnica. Eseje metafizyczne, Kraków 2009.

Sløk J., O pojęciu powtórzenia, [w:] S. Kierkegaard, Powtórzenie. Próba psychologii eksperymentalnej przez Constantina Constantinusa, przeł., wstępem i przypisami opatrzył B. Świderski, Warszawa 1992.

Zaworska H., Opowiadania Jarosława Iwaszkiewicza, Warszawa 1985. 